
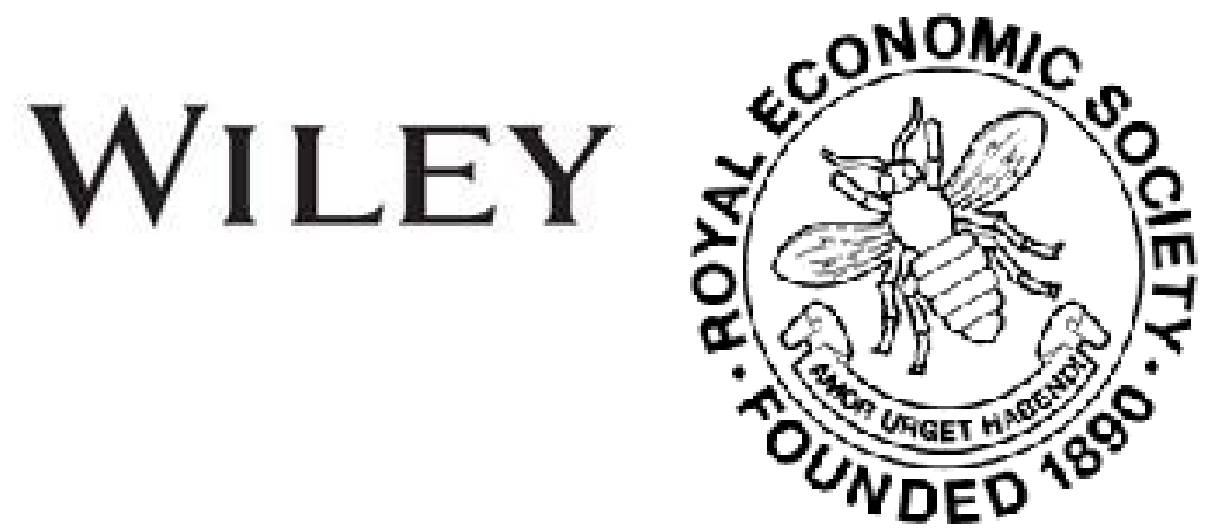

\title{
Review
}

Author(s): F. Lavington

Review by: F. Lavington

Source: The Economic Journal, Vol. 22, No. 86 (Jun., 1912), pp. 274-276

Published by: Wiley on behalf of the Royal Economic Society

Stable URL: http://www.jstor.org/stable/2221787

Accessed: 27-06-2016 05:11 UTC

Your use of the JSTOR archive indicates your acceptance of the Terms \& Conditions of Use, available at

http://about.jstor.org/terms

JSTOR is a not-for-profit service that helps scholars, researchers, and students discover, use, and build upon a wide range of content in a trusted digital archive. We use information technology and tools to increase productivity and facilitate new forms of scholarship. For more information about JSTOR, please contact support@jstor.org.

Wiley, Royal Economic Society are collaborating with JSTOR to digitize, preserve and extend access to The Economic Journal 
prices." That is, perhaps, the most crucial of present popular economic questions, and it must always occupy a prominent place in the scientific discussions of professional economists. On no other topic then could a new recruit "win his spurs" with a more favouring promise of abiding fame.

\section{L. PRICE}

Monetary Economics. By W. W. CARLILE. (London : Edward Arnold. 1912. Pp. xii +307 . 10s. 6d. net.)

IT is not easy to give briefly any very coherent account of Monetary Economics, partly because of the very wide field which it covers in the course of its 300 pages, partly because it does not belong to the vertebrate order of writings. There are, it is true, two main ideas. which the author is concerned to establish, but although these ideas may form the inspiration of his work, they do not constitute in any great measure the basis of the reasoning in the critical portions of it. Primarily, Mr. Carlile is dissatisfied with the present use of economic terms; secondarily, he maintains that economic phenomena can be properly understood only in terms of the money measure in which they are practically expressed. Like Faust, he rejects "In the beginning was the Word," and substitutes for it, "In the beginning was the Thought," but it is in the determination of whose thought where disagreement begins. There is a natural bounty upon simple solutions, but however firm may be the belief in a remote simplicity, it seems unreasonable to expect it in the more advanced phenomena of economics. When, therefore, Mr. Carlile lays down the principle not merely that the true meaning of economic terms is to be found from their popular usage, but that apart from that usage a technical expression is an arbitrary creation with no value or reality, he lays himself open to a charge of seeking a simplicity too far from the source. The argument leads him, naturally enough, to the conclusion that in so far as the popular ideas are pecuniary concepts, the science can rightly be presented only by means of these concepts, and money takes its place, not as a disguise which obscures the underlying equilibria of costs and satisfactions, but as the only form in which these phenomena may be presented or even contemplated. It is this view which constitutes, at any rate, the incentive to Mr. Carlile's criticism of orthodox economics, and which leads him to reject as unreal and useless the whole conception of the "margin." But even if it were granted that the marginal theory in its applications is a 
repetition of "must be's" which add nothing to knowledge, it must at least be admitted that it is a form of statement which points very clearly to the controlling causes of the phenomena to which it is applied.

The drift of Mr. Carlile's argument may be gathered from such paragraph headings as "The reliance on ambiguity," "Dr. Marshall's enigmatical attitude," and from the sentences: "He tells us that the marginal utility to a man of eight apples may be actually less than that of five of their number. He might just as well tell us that the whole may be less than the part." It is evident that Mr. Carlile is using terms in a sense quite different from that of the writers whom he opposes; his conclusion shows how greatly he has misapprehended their position: "But if in each case the marginal utility of the 'thing' . . . is defined by the utility of the marginal purchase, then the marginal utility of sugar would be just equal to the marginal utility of salt; and, by parity of reasoning, the marginal utility of gold must be just equal to the marginal utility of silver or iron. In fact, the marginal utilities of all exchangeable commodities must be equal inter se. If, again, we are to hold, with the theorists, that marginal utility is coincident with exchange value, then it follows that the exchange values of all commodities must also be equal to each other! Here, however, beyond question, we are face to face with a reductio ad absurdum of the whole marginal utility theory, if only the reductio ad absurdum itself had a definite and recognised place in the discussions of economics."

There is a good deal more critical work in Monetary Economics, much of it on minor points of theory. It is often difficult to follow the author in the course of his reasoning; the trail vanishes in some of the more difficult passages, and only reappears near the conclusion; but I take one among many unusual opinions where the argument and conclusion are too explicit to allow of any misunderstanding. Mr. Carlile, in the course of his rejection of the Quantity Theory, maintains that a rise in an index number does not (I think he would say can not) indicate a fall in the value of gold; he appears to hold that such a fall can take place only through a widespread mistrust of the metal; but he is quite definite in his conclusion, based, it seems, upon a consideration of the Law of Increasing Return, that "as regards the means of subsistence and as regards reproducible commodities generally, the tendency of an increased gold supply, and a consequently cheapened supply of loan money is to make them more abundant and cheaper in the long run." 
For the reasons already given, it is not possible, without danger of misrepresentation, to state briefly Mr. Carlile's conclusions with regard to Wages, Credit, and the other subjects with which he deals; but indeed his practical conclusions do not in general differ widely from those usually held; his concern is mainly with the reasoning by which those results are attained. The critical work which forms the greater part of the book is likely to attract that public which rejects as the work of theorists the most carefully established economic analyses, but no one interested in the science will escape a feeling of regret at the results of criticism founded on misapprehension, and the advertisement of bad arguments which have in reality no supporters.

\section{F. LAvington}

\section{Cours Elémentaire de Science des Finances. By Gaston Jèze.} (Paris: Giard. 1912. Pp. 1133.)

Althodgh the work of Professor Jèze has not hitherto been reviewed in the ECONOMIC JouRnAL, his reputation as a writer on public finance is firmly established. He is editor of the quarterly Revue de Science et de Législation Financières; he has published a large and valuable treatise on the general theory of the Budget which is intended to be but the first of a series of twelve volumes covering the whole field of finance; while the comprehensive work before us is the fifth edition of an elementary course which was first issued in collaboration with M. Max Boucard sixteen years ago.

After a brief introduction on the nature and scope of the science of finance, the author devotes the first section, embracing over four hundred closely printed pages, to the subjects of budgetary legislation and financial administration. While particular attention is given to French conditions, there are many valuable comparisons with the methods employed in other countries, and the information is remarkable for its accuracy and lucidity. To English readers, indeed, the space allotted to these questions may appear excessive, and may even deter those who are interested in the more distinctly economic branches of the subject, but the manual is specially adapted to the needs of students in the faculties of law of the Universities of France. The second and third sections, dealing with public expenditure and debts, are relatively brief, while the fourth and longest section is concerned with public revenue and the principles of taxation. Within each of the four sections chapters are reserved for the treatment 